\title{
CORRIGENDUM \\ Beneficial effects of early hemostasis on spinal cord injury in the rat
}

H Fan, K Chen, L Duan, Y-Z Wang and G Ju

Spinal Cord (2016) 54, 1058; doi:10.1038/sc.2016.97; published online 21 June 2016

Correction to: Spinal Cord (2016) 54, 924-932; doi: 10.1038/ sc.2016.58; published online 3 May 2016

\author{
Updated online 21 June 2016: This Article was originally \\ published under NPG's License to Publish, but has now been \\ made available under a CC BY-NC-SA 4.0 license. The PDF \\ and HTML versions of the paper have been modified \\ accordingly. \\ (n)
}

(c) (i) (2) (2) This work is licensed under a Creative Commons Attribution-NonCommercial-ShareAlike 4.0 International License. The images or other third party material in this article are included in the article's Creative Commons license, unless indicated otherwise in the credit line; if the material is not included under the Creative Commons license, users will need to obtain permission from the license holder to reproduce the material. To view a copy of this license, visit http://creativecommons.org/licenses/bync-sa/4.0/ 